\title{
Pengaruh Penggunaan Konteks Daun terhadap Hasil Belajar Siswa
}

\author{
Lisnani \\ Pendidikan Guru Sekolah Dasar, Universitas Katolik Musi Charitas \\ Jalan Bangau No. 60, Palembang, Sumatera Selatan, Indonesia \\ lisnani@ukmc.ac.id
}

Artikel diterima: 09-08-2019, direvisi: 20-09-2019, diterbitkan: 30-09-2019

\begin{abstract}
Abstrak
Latar belakang penelitian yaitu kesulitan dalam mempelajari materi pecahan, dengan tujuan mengetahui pengaruh penggunaan konteks daun sebagai solusi permasalan materi pecahan terhadap hasil belajar pecahan siswa SD Kelas IV. Jenis penelitian adalah penelitian eksperimen. Populasi dalam penelitian ini berjumlah 76 orang yang terdiri 3 kelas yaitu IV A, IV B, dan IV C. Sampelnya berjumlah 50 orang yang terdiri dari kelas IV A dan IVB masing-masing berjumlah 25 orang. Penelitian ini dilakukan di SD Negeri 42 Palembang. Teknik pengumpulan data menggunakan wawancara yang dilakukan terhadap guru terkait dengan penggunaan konteks daun pada materi pecahan, tes untuk mengukur hasil belajar siswa, dan dokumentasi. Teknik analisa data menggunakan uji normalitas, uji homogenitas, dan independent sample t-test melalui SPSS. Hasil dari penelitian ini adalah adanya pengaruh penggunaan konteks daun terhadap hasil belajar pecahan siswa SD kelas IV. Penggunaan konteks daun sangat membantu siswa dalam pembelajaran matematika pada topik pecahan.

Kata Kunci: konteks, daun, pecahan, hasil belajar.
\end{abstract}

\section{The Effect of Use of Leaf Context on Students' Learning Outcomes}

\begin{abstract}
The background of this study is the difficulty in studying fracton material, with purpose about the use of leaves on the learning outcomes of elementary school students' fractional grades IV. This type of research used in this study is research. The population in this study was 76 people consisting of 3 classes namely IV A, IV B, and IV C. The samples were collected 50 people consisting of classes IV A and IVB, each of which could be taken, 25 people. This research was conducted at 42nd SD Negeri Palembang. Data collection techniques using interviews conducted with teachers related to the use of context in fraction material tests to measure student learning outcomes and implementation. Data analysis techniques using homogeneity test, normality test, and independent sample t-test through SPSS. The results of this study are the results of the use of leaf interactions on the learning outcomes of elementary school students' fractional grades IV.

Keywords: context, leaves, fractions, learning outcomes.
\end{abstract}




\section{Pendahuluan}

Kurikulum pendidikan di Indonesia mengalami perubahan yang cukup signifikan dari waktu ke waktu, bahkan terkesan tidak stabil, ganti menteri ganti kurikulum. Menurut Mahmedi (2016), kurikulum didefinisikan sebagai aspek yang berpengaruh langsung terhadap hasil pendidikan.

Kurikulum di Indonesia terus mengalami pembaharuan dari waktu ke waktu. Kurikulum yang berlaku di abad 21 adalah kurikulum 2013. Di dalam kurikulum 2013, pembelajaran matematika memegang peranan penting di bidang pendidikan.

Matematika dipandang sebagai dasar yang digunakan untuk menguasai mata pelajaran lain dan dasar dalam perkembangan ilmu pengetahuan dan teknologi (Purwanto \& Yusfika, 2013). Matematika sendiri sudah dipelajari oleh siswa sejak tingkat sekolah dasar hingga perguruan tinggi mulai dari konsep dasar pecahan hingga soal pemecahan masalah.

Ada beberapa materi matematika yang menjadi kesulitan bagi siswa di tingkat sekolah dasar salah satunya adalah pecahan. Sama seperti halnya dengan pendapat yang dikemukakan oleh Nababan dan Hendra (2016) bahwa pecahan merupakan salah satu topik matematika yang sulit untuk diajarkan.

Padahal pembelajaran pecahan merupakan dasar yang digunakan untuk materi berikutnya dan juga menjadi dasar mata pelajaran lain di tingkatan berikutnya seperti Fisika maupun Kimia. Pecahan adalah gambaran dari suatu bilangan (relasi) antara satu bilangan dengan bilangan lain (Van de Walle, 2013). Lebih jelas diungkapkan oleh Musser et al (2011) yang mendefinisikan pecahan sebagai bilangan yang dapat direpresentasikan sebagai bagian dari keseluruhan dimana a $\neq 0$ dengan himpunan pecahan sebagai: $\{\mid$ a dan $b$ bilangan asli, $b \neq 0$.

Berdasarkan pengalaman peneliti, sebagian besar guru yang mengajar matematika merupakan guru kelas yang bidang keilmuannya bukan matematika sehingga guru tersebut hanya mengajar berdasarkan contoh pada buku pegangan guru yang sudah disediakan sekolah.

Di samping itu, beberapa soal latihan pada buku pegangan tidak dapat dijawab oleh guru. Prosedur yang sama diulangi terus oleh guru dalam mengajar matematika termasuk materi pecahan. Maka dari itu, siswa cenderung mengerjakan soal latihan berdasarkan contoh soal tanpa memahami konsep bilangan pecahan.

Tak hanya itu, sebagian besar guru mengajarkan operasi penjumlahan dan pengurangan pecahan dengan menyamakan penyebut kedua bilangan pecahan menggunakan KPK kemudian membandingkan pecahan. Namun, cara ini tidak dapat membantu siswa karena siswa belum belajar tentang KPK pada saat belajar bilangan pecahan sederhana.

Di samping pengalaman peneliti, peneliti juga melakukan wawancara kepada tiga orang guru kelas IV di SD Negeri 42 Palembang, informasi yang 
diperoleh dari hasil wawancara adalah sebagai berikut: 1) guru jarang menggunakan konteks di dalam pembelajaran matematika terkait materi pecahan; 2) rendahnya hasil belajar siswa terlihat dari hanya $40 \%$ siswa yang mencapai KKM.

Hasil belajar yang dicapai seseorang dalam pembelajaran berupa nilai atau skor" (Padeng, 2017). Menurut Wahyuningtyas dan Amanda (2017), hasil belajar didefinisikan sebagai kemampuan yang dimiliki siswa sebagai akibat aktivitas belajar siswa yang dapat diamati melalui penampilan siswa. Siswa akan lebih bersemangat belajar jika diberikan skor terhadap kemampuan atau keterampilan yang dimilikinya setelah mengikuti proses belajar.

Pembelajaran pecahan dirasakan lebih menarik jika menggunakan konteks seperti konteks pembagian kue yang disajikan dalam bentuk gambar. Penggunaan konteks sebagai starting point pembelajaran adalah pendekatan pembelajaran Pendidikan Matematika Realistic Indonesia (PMRI). Penggunaan konteks harus dapat dapat diperagakan langsung oleh siswa dan disesuaikan dengan karakteristik siswa.

Maka dari itu, peneliti tertarik menggunakan konteks berupa daun di dalam pembelajaran pecahan sebagai karakteristik dari pendekatan PMRI (Pendidikan Matematika Realistik Indonesia). Dikatakan demikian karena daun menjadi konteks di dalam pembelajaran matematika. Melalui Mosharafa: Jurnal Pendidikan Matematika Volume 8, Nomor 3, September 2019 Copyright @ 2019 Mosharafa: Jurnal Pendidikan Matematika penggunaan daun sebagai konteks, ini menjadikan pembelajaran matematika yang awalnya abstrak menjadi real (nyata) bagi siswa. Dalam PMRI, realistic itu sendiri tidak perlu nyata, cukup hanya dapat dibayangkan oleh siswa (Afriansyah, 2016).

Daun digunakan dalam pembelajaran ini berdasarkan warna daun. Saat siswa menyamakan pecahan senilai maka yang digunakan adalah warna daun. Siswa menyusun daun-daun yang sama warnanya dengan soal pecahan yang diberikan oleh guru. Di samping itu, peneliti menggunakan daun untuk memperkenalkan pecahan dengan cara membagi daun tersebut menjadi beberapa bagian.

Karakteristik PMRI menurut Sembiring, Hoogland, dan Dolk (2010) diantaranya sebagai berikut: 1) penggunaan konteks pada eksplorasi; 2) penggunaan model; 3) Penggunaan kreasi dan kontribusi siswa. 4) interaktifitas.; 5) keterkaitan; 6) menggunakan karakteristik alam dan budaya Indonesia.

Tidak hanya itu, penggunaan konteks daun pun sangat efektif karena siswa belajar dari lingkungan sekitarnya (di luar kelas/outdoor). Tak hanya itu, pembelajaran yang dialami siswa pun menjadi lebih bermakna. Melalui serangkaian aktivitas pembelajaran yang dirancang peneliti membuat siswa menjadi lebih aktif dan kreatif. Hal ini sejalan dengan pandangan konstruktivisme yang menyatakan bahwa anak secara aktif mengkonstruksi pengetahuan dengan secara berkesinambungan dengan cara 
mengasimilasi dan mengakomodasi

informasi baru yang menekankan peran aktif siswa dalam membangun pemahaman mereka tentang realita (Slavin, 1994).

Ada beberapa penelitian yang dilakukan oleh peneliti sebelumnya terkait materi pecahan antara lain: Pertama, penelitian yang dilakukan oleh Afriansyah (2012) dengan judul "Implementasi PMRI dalam Materi Sifat Komutatif dan Assosiatif pada Bilangan Bulat untuk Level Siswa SD/MI". Hasil yang diperoleh dari penelitian ini adalah tiap aktivitas pembelajaran yang diterapkan dapat memberikan pemahaman kepada siswa dari situasi kontekstual sampai situasi yang lebih formal.

Kedua, penelitian yang dilakukan oleh Purwanto dan Yusfika (2013) dengan judul "Penggunaan Media Blok Pecahan dalam Meningkatkan Hasil Belajar Matematika Materi Pengurangan Pecahan di Sekolah Dasar". Diperoleh hasil penelitian pembelajaran dengan menggunakan media blok pecahan dapat meningkatkan hasil belajar siswa pada materi pengurangan pecahan di sekolah dasar.

Ketiga, penelitian yang dilakukan oleh Edo dan Samo (2017) dengan judul "Lintasan Pembelajaran Pecahan Menggunakan Matematika Realistik Konteks Permainan Tradisional Siki Doka". Diperoleh hasil penelitian yaitu siswa sangat antusias dan menikmati seluruh aktivitas pembelajaran dan siswa bukan saja telah memahami konsep pecahan sederhana, membandingkan pecahan 426 sederhana, dan memecahkan masalah yang berkaitan dengan pecahan sederhana.

Keempat, penelitian yang dilakukan oleh Wardana \& Damayani (2017) dengan judul "Persepsi Siswa terhadap Pembelajaran Pecahan di Sekolah Dasar". Hasil yang diperoleh dari penelitian ini adalah persepsi siswa belajar pecahan harus dimulai dengan pengenalan masalah atau dengan meningkatkan masalah yang lebih nyata dengan menghubungkan pembelajaran ke kehidupan sehari-hari.

Kelima, penelitian yang dilakukan oleh Rahayu (2018) dengan judul "Pengembangan Alat Peraga Papan Pelangi pada Operasi Hitung Pecahan di Sekolah Dasar". Diperoleh hasil pengembangan inovasi pembelajaran menunjukan presentase hasil belajar peserta didik mengalami peningkatan dari 60,33\% menjadi 70,33\% pada uji coba 1 dan semakin meningkat pada uji coba 2 menjadi $82,67 \%$.

Keenam, penelitian uang dilakukan oleh Warsito, Nuraini, dan Sukirwan (2019) dengan judul "Desain Pembelajaran Pecahan melalui Pendekatan Realistik di Kelas V". Hasil dari penelitian ini adalah serangkaian kegiatan pembelajaran dengan PMR dapat membawa siswa dari situasi konkret menuju situasi yang lebih formal.

Perbedaan penelitian ini dengan peneliti sebelumnya adalah peneliti menggunakan konteks berupa daun dalam penelitian guna mengetahui pengaruh konteks daun terhadap hasil belajar siswa 
SD kelas IV. Rumusan masalah dalam penelitian ini adalah: bagaimana pengaruh penggunaan konteks daun terhadap hasil belajar pecahan siswa SD kelas IV? Adapun secara garis besar tujuan dari penelitian ini adalah mengetahui pengaruh penggunaan konteks daun sebagai solusi permasalan materi pecahan terhadap hasil belajar pecahan siswa SD Kelas IV.

\section{Metode}

Metode penelitian yang digunakan dalam penelitian ini adalah metode penelitian eksperimen yang tergolong jenis penelitian kuantitatif. Variabel penelitian adalah segala sesuatu yang berbentuk apa saja yang ditetapkan oleh peneliti untuk dipelajari sehingga diperoleh informai tentang hal tersebut, kemudian ditarik kesimpulan (Sugiyono, 2015). Di dalam penelitian ini terdapat dua variabel penelitian yaitu media daun sebagai variabel bebas sedangkan hasil belajar sebagai variable terikat.

Hipotesis merupakan jawaban sementara terhadap masalah penelitian yang menyangkut perilaku, gejala, kejadian, kondisi, dan fakta sesuatu hal yang telah terjadi maupun untuk masa yang akan mendatang (Suprapto, 2013). Adapun hipotesis dalam penelitian ini terdiri dari:

$\mathrm{H}_{\mathrm{a}}=$ ada pengaruh penggunaan konteks daun terhadap hasil belajar pecahan siswa SD kelas IV

$\mathrm{H}_{0}=$ tidak ada pengaruh penggunaan konteks daun terhadap hasil belajar pecahan siswa SD kelas IV
Penelitian ini dilakukan di SD Negeri 42 Palembang pada semester ganjil tahun pelajaran 2018/2019.

Di dalam penelitian ini terdapat populasi penelitian. Populasi adalah keseluruhan kelompok manusia, kejadian (peristiwa), atau benda (sesuatu) yang diminati peneliti untuk bisa dilakukan penganggapan umum (generalisasi) atas hasil suatu penelitian (Gumanti, Yunidar, \& Syahrudin, 2016). Adapun populasi dalam penelitian ini seperti tabel 1 .

Tabel 1 menjelaskan bahwa populasi dalam penelitian ini berjumlah 76 orang yang terdiri dari 3 kelas yaitu kelas IVA, IVB, dan IVC. Di samping populasi, penelitian ini difokuskan pada sampel penelitian. Gumanti, Yunidar, dan Syahrudin (2016), sampel adalah subset atau dapat dikatakan sebagai bagian dari jumlah populasi. Sampel harus diambil dari bagian populasi. Pengambilan sampel harus mencukupi dan mewakili populasi yang akan diteliti (Sukardi, 2016).

Teknik pengambilan sampel yang akan digunakan dalam penelitian ini yaitu probability sampling menggunakan jenis teknik simple random sampling (sampel acak) dimana seluruh anggota atau populasi memiliki kesempatan yang sama untuk dipilih menjadi sampel (Lisnani,

Tabel 1.

Populasi Penelitian

\begin{tabular}{|ccccc|}
\hline No & Kelas & L & P & Jumlah \\
\hline 1 & IV.A & 15 & 10 & 25 \\
\hline 2 & IV.B & 14 & 11 & 25 \\
\hline 3 & IV.C & 17 & 9 & 26 \\
\hline & Total & 46 & 30 & 76 \\
\hline
\end{tabular}


2019). Adapun sampel dalam penelitian ini seperti tabel 2.

Berdasarkan tabel 2, diperoleh data bahwa kelas IV.A merupakan kelas eksperimen (kelas yang menggunakan konteks daun di dalam pembelajaran pecahan) sedangkan kelas IVB. merupakan kelas kontrol (kelas yang tidak menggunakan konteks daun di dalam pembelajaran pecahan).

Teknik pengumpulan data yang digunakan dalam penelitian ini yaitu wawancara, dokumentasi, dan tes. Wawancara dilakukan secara langsung terhadap guru bertujuan untuk mengetahui apakah di sekolah tersebut pernah menggunakan konteks daun di dalam pembelajaran pecahan dan rendahnya hasil belajar siswa terlihat dari hanya 40\% siswa yang mencapai KKM. Dokumentasi bertujuan untuk mendeskripsikan proses pembelajaran pecahan menggunakan konteks daun yang dilakukan oleh siswa sejak awal pembelajaran hingga pada pelaksanaan posttest sebanyak $3 x$ pertemuan. Peneliti mendokumentasikan saat siswa mengerjakan soal posttest dan hasil kerja siswa.

Tes berguna untuk mengetahui hasil belajar siswa. Tes yang diberikan oleh

Tabel 2

Sampel Penelitian

\begin{tabular}{cccccc}
\hline No & Kelas & L & P & Jumlah & Keterangan \\
\hline 1 & IV.A & 15 & 10 & 25 & $\begin{array}{c}\text { Kelas } \\
\text { eksperimen }\end{array}$ \\
\hline 2 & IV.B & 14 & 11 & 25 & $\begin{array}{c}\text { Kelas } \\
\text { kontrol }\end{array}$ \\
\hline
\end{tabular}

peneliti berupa soal essay dalam bentuk pemecahan masalah berkonteks PMRI tentang pecahan senilai sebanyak 10 soal. Jumlah soal awal yang diberikan peneliti untuk divalidasi berjumlah 20 soal, dari 20 soal tersebut hanya 10 soal yang valid dan reliable setelah dilakukan uji validitas dan reliabilitas menggunakan uji Cronbach Alpha.

Teknik analisa data menggunakan uji normalitas, uji homogenitas dan uji independent sample t-test. Uji normalitas bertujuan untuk mengetahui apakah data terdistribusi normal. Sementara itu, uji homogenitas diperlukan untuk mengetahui apakah suatu data yang akan diteliti itu homogen. Sedangkan uji independent sample t-test bertujuan untuk mengetahui pengaruh konteks daun terhadap hasil belajar siswa melalui posttest siswa yang menggunakan konteks daun dalam pembelajaran pecahan.

\section{Hasil dan Pembahasan}

\section{A. Hasil}

\section{Uji Normalitas}

Sebelum melakukan penelitian, peneliti melakukan uji normalitas. Uji normalitas bertujuan untuk mengetahui apakah data terdistribusi normal atau tidak. Adapun hasil uji normalitas menggunakan SPSS seperti pada Tabel 3.

Berdasarkan tabel 3, diketahui bahwa variabel kelompok media daun mempunyai nilai sig $=0.111$ yang berarti lebih dari 0.05 atau dapat disimpulkan 
bahwa kelompok media daun mempunyai sebaran data yang normal dan kelompok tanpa media daun mempunyai nilai sig = 0.100 yang berarti lebih dari 0.05 atau dapat disimpulkan bahwa kelompok tanpa media daun mempunyai sebaran data yang normal

\section{Uji Independent Sample T-Test}

Hipotesis pada penelitian ini dibuktikan menggunakan uji independent sample ttest dideskripsikan pada tabel 4 berikut.

Tabel 4 menunjukkan bahwa nilai ratarata hasil belajar matematika siswa yang

Tabel 3.

Uji Normalitas

Tests of Normality

\begin{tabular}{llllllll}
\hline & \multicolumn{3}{c}{$\begin{array}{c}\text { Kolmogorov- } \\
\text { Smirnova }\end{array}$} & & & & Shapiro-Wilk \\
\cline { 2 - 7 } & $\begin{array}{c}\text { Statist } \\
\text { ic }\end{array}$ & Df & Sig. & Statistic & Df & Sig. \\
\hline $\begin{array}{l}\text { Kelompok } \\
\text { menggunak } \\
\text { an konteks } \\
\text { daun }\end{array}$ & .183 & 22 & .053 & .928 & 22 & .111 \\
$\begin{array}{l}\text { Kelompok } \\
\text { tanpa } \\
\text { menggunak } \\
\text { an konteks } \\
\text { daun }\end{array}$ & .241 & 22 & .002 & .755 & 22 & .100 \\
\hline
\end{tabular}

Tabel 4.

Hasil Uji Independent Sample T-Test

Group Statistics

\begin{tabular}{|c|c|r|r|r|}
\hline Kelompok & $\mathrm{N}$ & Mean & $\begin{array}{c}\text { Std. } \\
\text { Deviation }\end{array}$ & $\begin{array}{c}\text { Std. } \\
\text { Error } \\
\text { Mean }\end{array}$ \\
\hline Nilai $\begin{array}{c}\text { Kelompok } \\
\text { Media Daun } \\
\text { Kelompok } \\
\text { Tanpa } \\
\text { Media Daun }\end{array}$ & 24 & 69.17 & 18.434 & 3.763 \\
\hline
\end{tabular}

menggunakan media daun (sebesar 69,17) lebih tinggi daripada nilai rata-rata siswa yang tidak mengggunakan media daun (sebesar 31,73).

\section{B. Pembahasan}

Pada pembelajaran ini, peneliti menggunakan media daun, dimana siswa belajar menggunakan konteks daun pada materi pecahan senilai secara keseluruhan karena konteks daun ada di lingkungan sekitar siswa dan mudah dicari saat proses pembelajaran berlangsung. Adapun seperti gambar 1 dan 2 .

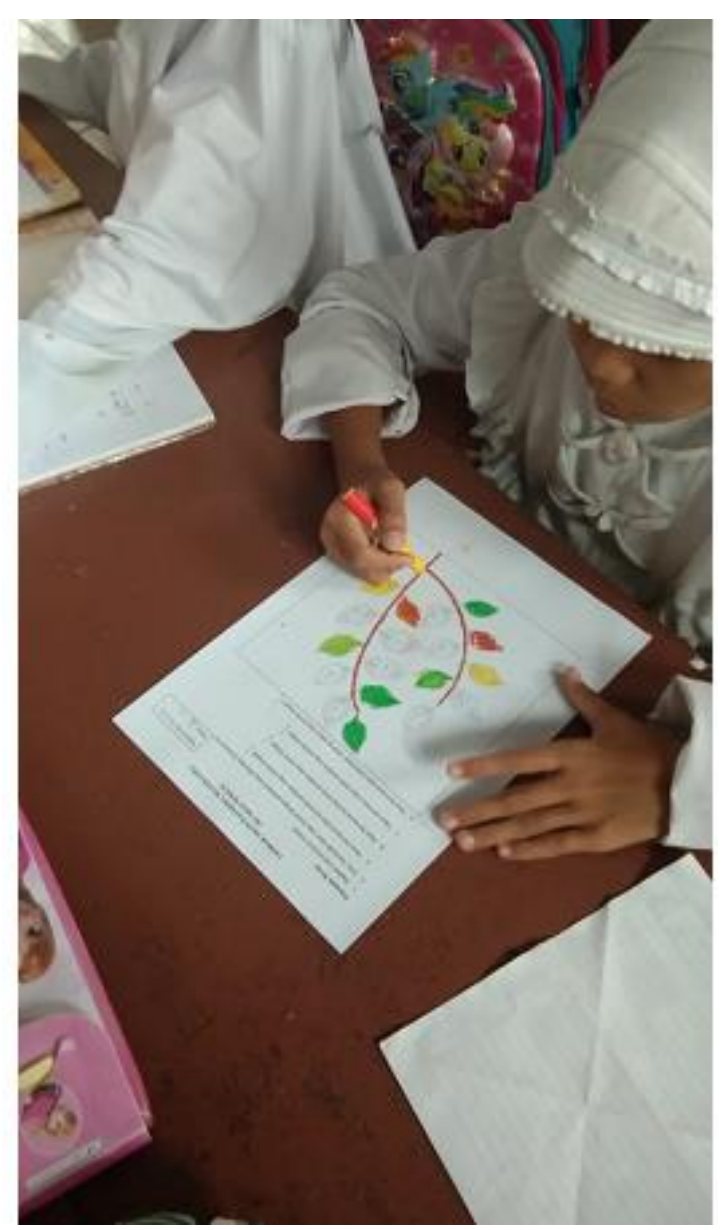

Gambar 1. Siswa Mengerjakan Soal 
Gambar 1 menunjukkan bahwa siswa terhadap konsep dasar pecahan senilai tampak antusias mengerjakan soal dengan kemampuan siswa menggunakan tersebut. Hal ini dikarenakan adanya warna (terkait dengan ketelitian siswa). pengembangan pemahaman siswa Sedangkan gambar 2, terlihat siswa

\section{L.MBAR AKTIVTTAS SISWA MATrMATTKA} PECAHAN SENILAI

\section{Petuajuk Kerja:}

1. Siapkan crayonjpensil warna!

2. Lalu, wamailah daun yang sesuai dengan petunjuk yang diberikan di bawah ini!

2. Daun berwama hijau tua untuk pecahan yong seailai dengan $\frac{1}{3}$

b. Daun berwarna kuning untuk pecahan yang senilai dengan $\frac{1}{4}$

c. Daun berwana caklat untak pecahan yang setrilai dengan $\frac{1}{5}$

d. Daun berwarna hijau kekuningan untuk pecahan yang senilai dengan $\frac{2}{3}$

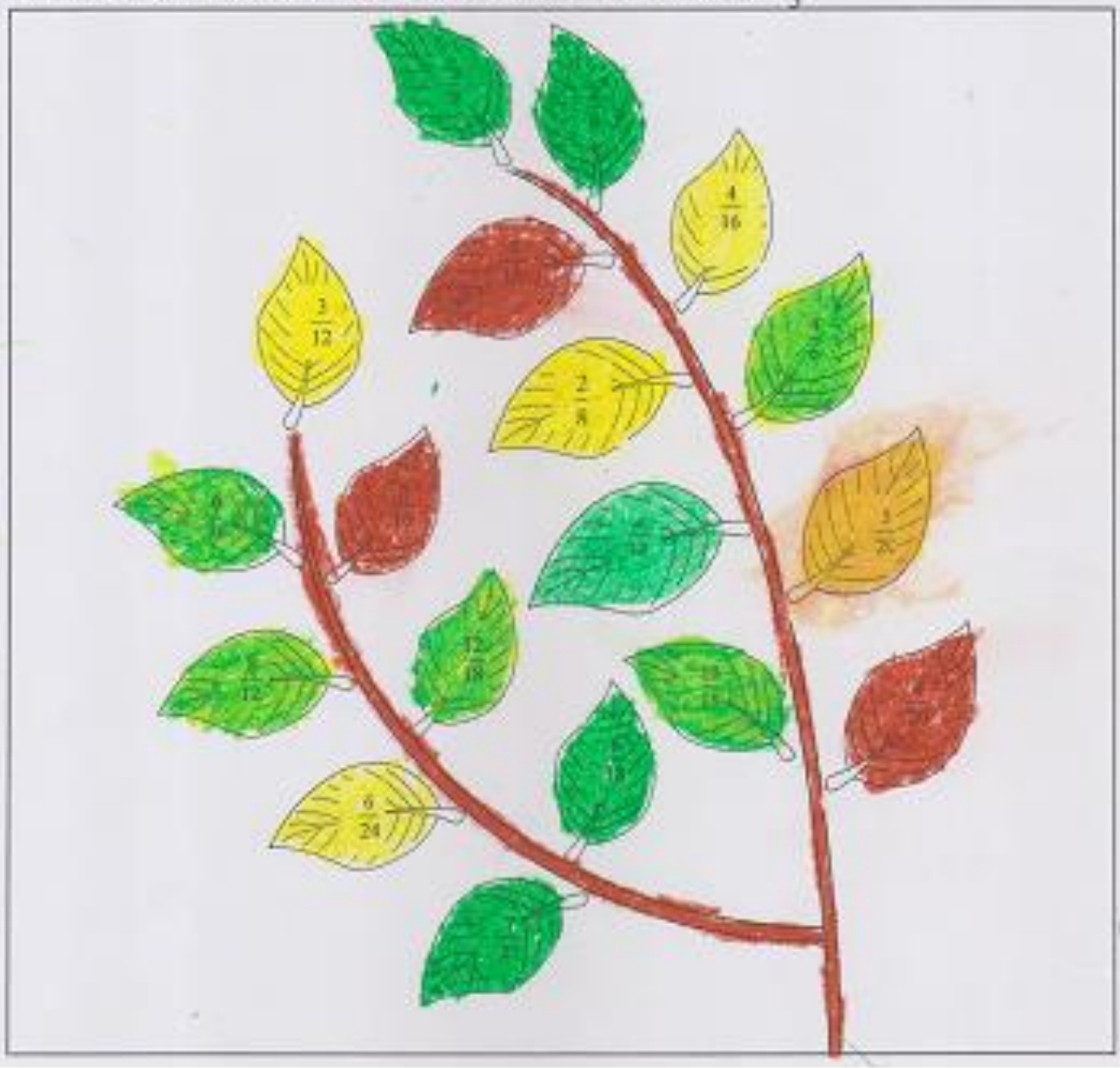

Gambar 2. Hasil Kerja Siswa 
sedikit mengalami kesulitan menentukan warna hijau kekuning-kuningan. Namun, secara keseluruhan siswa mengerti maksud dari pertanyaan yang diberikan guru.

Pada lembar kerja yang dikerjakan siswa, siswa diminta mencari pecahan senilai dari $\frac{1}{3}, \frac{1}{4}, \frac{1}{5}$, dan $\frac{2}{3}$. Ketika siswa dapat menentukan pecahan senilai itu, siswa harus mewarnai setiap bagian daun tersebut. Contohnya pecahan senilai dari $\frac{1}{3}$ adalah $\frac{2}{6}, \frac{3}{9}, \frac{4}{12}, \frac{5}{15}, \frac{6}{18}$, dan $\frac{7}{21}$.

Setelah siswa berhasil menentukan pecahan senilai tersebut, siswa mewarnai daun-daun tersebut dengan spidol/crayon/pensil warna dengan warna hijau tua pada tiap daun tersebut.

Penggunaan konteks ini erat kaitannya dengan pendekatan PMRI. Di dalam pendekatan PMRI ada beberapa karakteristik yang muncul antara lain keterkaitan antara materi satu dengan materi lain.

Berdasarkan hasil analisis data menunjukkan adanya pengaruh penggunaan konteks daun terhadap hasil belajar siswa kelas IV SD Negeri ini dikarenakan siswa dilatih secara aktif dan kreatif memahami konsep dasar pecahan senilai dan mempelajari materi pecahan secara real sesuai dengan karakteristik dari pendekatan PMRI.

Di dalam pendekatan PMRI penggunaan konteks daun dalam pembelajaran pecahan sangat membantu siswa agar lebih memahami tentang pecahan senilai.

\section{Penutup}

Melalui penggunaan konteks daun sangat membantu siswa dalam pembelajaran matematika pada topik pecahan. Siswa belajar secara langsung konsep tentang pecahan dari pengenalan pecahan, pecahan senilai, dan operasi pecahan.

Dengan kata lain, penggunaan konteks daun ini berpengaruh terhadap hasil belajar siswa pada materi pecahan. Penggunaan konteks ini juga dapat melatih semangat siswa dalam pembelajaran tentang pecahan.

\section{UCAPAN TERIMA KASIH}

Peneliti mengucapkan kepada seluruh pihak SD Negeri 42 Palembang yaitu Kepala Sekolah, guru kelas IV, dan siswa kelas IV yang bersedia menjadi subjek penelitian di dalam penelitian ini. Di samping itu, peneliti juga mengucapkan terima kasih kepada Universitas Katolik Musi Charitas yang telah mendukung peneliti di dalam penelitian ini.

\section{DAFTAR PUStaka}

Afriansyah, E. A. (2012). Implementasi PMRI dalam Materi Sifat Komutatif dan Assosiatif pada Bilangan Bulat untuk Level Siswa SD/MI. Mosharafa: Jurnal Pendidikan Matematika, 1(2). 67-72.

DOI: https://doi.org/10.31980/moshar afa.v1i2.175 
Afriansyah, E. A. (2016). Makna Realistic dalam RME dan PMRI. LEMMA, 2(2), 96-104.

Edo, S. I. \& Samo, D. D. (2017). Lintasan Pembelajaran Pecahan Menggunakan Matematika Realistik Konteks Permainan Tradisional Siki Doka. Mosharafa: Jurnal Pendidikan Matematika, 6(3). 311-322. DOI: https://doi.org/10.31980/moshar afa.v6i3.320

Gumanti, T. A., Yunidar, \& Syahrudin. (2016). Metode Penelitian Pendidikan. Jakarta: Mitra Wacana Media.

Lisnani. (2019). Pengaruh Model Pembelajaran Example Non Example untuk Meningkatkan Hasil Belajar Tematik bagi Siswa Kelas VI SD". Jurnal Basicedu, 3(1). 76-82.

Mahmedi. (2016). Perubahan Kurikulum di Indonesia: Studi Kritis Tentang Upaya Menemukan Kurikulum Pendidikan Islam yang Ideal. Jurnal Raudhah, IV(1). 49-70.

Musser, G.L. et.al. (2011). Mathematic for elementary Teachers A Contemporary Approach (Ninth edition). Florida: Jhon Wiley \& Sons, Inc.

Nababan, S.A., \& Hendra, S.T. (2016). Pengaruh Penggunaan Metode Pembelajaran Bermain Terhadap Hasil Belajar Matematika Siswa Materi Pokok Pecahan di Kelas III SD Negeri 200407 Hutapadang". Jurnal Bina Gogik, 3(1). 35-42.

Padeng, S. (2017). Peningkatan Minat dan Prestasi Belajar Menggunakan Pendekatan PMRI pada Mata
Pelajaran Matematika untuk Siswa Kelas III SD Kanisius Klepu. Skripsi. Yogyakarta: Universitas Sanata Dharma.

Purwanto, \& Yusfika, O. (2013). Penggunaan Media Blok Pecahan dalam Meningkatkan Hasil Belajar Matematika Materi Pengurangan Pecahan di Sekolah Dasar. JPGSD, 01 (02). 1-10.

Rahayu, Y. (2018). Pengembangan Alat Peraga Papan Pelangi pada Operasi Hitung Pecahan di Sekolah Dasar. Jurnal Dikdaktika Pendidikan Dasar, 2(2). 37-53.

Sembiring, R. K., Hoogland, K. \& Dolk, M. (2010). A decade of PMRI in Indonesia. Bandung-Utrecht: APS International.

Sugiyono. (2015). Metode Penelitian Pendidikan Pendekatan Kuantitatif, Kualitatif, dan R\&D. Bandung: Alfabeta.

Sukardi. (2016). Metodologi Penelitian Pendidikan Kompetensi dan Praktiknya. Jakarta: PT Bumi Aksara.

Suprapto. (2013). Metodologi Penelitian IImu Pendidikan dan IImu-IImu Pengetahuan Sosial. Yogyakarta: CAPS (Center of Academic Publishing Service).

Van de Walle, J. (2013). Elementary and Middle School Mathematics Teaching and Developmentally. Boston: Perso Education, Inc.

Wahyuningtyas, D.T., \& Amanda, P. (2017). Eksperimen Model Pembelajaran Teams Games Tournament (TGT) 
Berbantuan Media Keranjang Biji-

Bijian Terhadap Hasil Belajar Materi

Perkalian dan Pembagian Siswa Kelas

II SDN Saptorenggo 02. Jurnal IImiah

Sekolah Dasar, 1(3). 163-170.

Wardana, M. Y. S., \& Damayani, A. T. (2017). Persepsi Siswa terhadap Pembelajaran Pecahan di Sekolah Dasar. Mosharafa: Jurnal Pendidikan Matematika, 6(3). 451-462. DOI: https://doi.org/10.31980/mosha rafa.v6i3.333

Warsito, W., Nuraini, Y., \& Sukirwan, S. (2019). Desain Pembelajaran Pecahan melalui Pendekatan Realistik di Kelas V. Mosharafa: Jurnal Pendidikan Matematika, 8(1). 25-36.
DOI: https://doi.org/10.31980/mosha rafa.v8i1.381

\section{Riwayat Hidup PENUlis}

Lisnani, M.Pd.

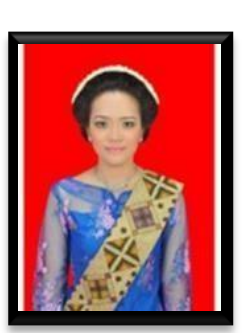

Lahir di Palembang, 19 September 1987. Sekretaris Program Studi PGSD di Universitas Katolik Musi Charitas. Studi: S1 Pendidikan Fisika di Universitas PGRI Palembang, tahun 2006 dan lulus tahun 2010; S2 Pendidikan Matematika di Universitas Sriwijaya Palembang, Sumatera Selatan; dan S2 Pendidikan Matematika di Universitas Sriwijaya Palembang, Sumatera Selatan, sampai dengan sekarang. 
Thispage is intentionally left blank 